\title{
Dampak Pembuangan Limbah Domestik terhadap Pencemaran Air Tanah di Kabupaten Pidie Jaya
}

\author{
Muhammad Gufran ${ }^{1,}$ Mawardi ${ }^{2, *}$ \\ ${ }^{1}$ Fakultas Kesehatan Masyarakat Universitas Muhammadiyah Aceh - Banda Aceh \\ ${ }^{2}$ Balai Pelatihan Kesehatan Aceh - Banda Aceh \\ Koresponden email: mawardi.ibrahim@gmail.com
}

Diterima: 30 Desember 2018

Disetujui: 9 Februari 2019

\begin{abstract}
One parameter of water quality is bacteriological content. Among the factors causing increased bacteriological content in water (SGL) are domestic waste. This study aims to determine the quality of water (SGL) in Keude Lueng Putu Village biologically, knowing whether distance (SGL) from polluting sources meets the requirements or not, determining whether physical conditions and construction (SGL) meet the requirements or not, and identify user behavior (SGL). The population in this study was 121 units (SGL) and those taken into samples using the Simple Random Sample technique were $10 \%$ of the total (SGL), which was 12 (SGL). For the independent variable distance / location of pollutant sources with bacteriological quality of water with indicators of Coliform levels, it shows that the farther the distance of the pollutant source the lower the Coliform level (having a negative correlation). While the correlation between the distance / location of pollutant sources with E. coli levels is very weak (Pearson correlation value is very small $(0.013)$.Correlation test for the second independent variable shows that the physical condition (SGL) does not have a significant effect on Coliform levels ( $\mathrm{p}$ value 0.558 ), while E. coli levels show a correlation between construction (SGL) and E. coli levels, although this relationship is very weak because the $p$ value is 0.067 . The third independent variable explains the behavior of the people which greatly influences Coliform levels in water (SGL) indicated by ( $p$ value) is $0.001(<0.05)$.
\end{abstract}

Keywords: Groundwater pollution, bacteriological content, coliform, e.coli, Pidie Jaya

\begin{abstract}
Abstrak
Salah satu parameter kualitas air adalah kandungan bakteriologis. Diantara faktor penyebab meningkatnya kandungan bakteriologis dalam air (SGL) adalah limbah domestik. Penelitian ini bertujuan untuk menentukan kualitas air (SGL) di Desa Keude Lueng Putu secara biologis, mengetahui apakah jarak (SGL) dari sumber pencemar memenuhi syarat atau tidak, menentukan apakah kondisi fisik dan konstruksi (SGL) memenuhi syarat atau tidak, dan mengidentifikasi perilaku pengguna (SGL). Populasi dalam penelitian ini adalah 121 unit (SGL) dan yang diambil menjadi sampel dengan menggunakan teknik Sampel Acak Sederhana adalah 10\% dari jumlah total (SGL) yaitu sebanyak 12 (SGL). Untuk variabel independen jarak/letak sumber pencemar dengan kualitas bakteriologis air dengan indikator kadar Coliform, menunjukkan bahwa semakin jauh jarak sumber pencemar semakin kecil kadar Coliformnya (memiliki korelasi negatif). Sedangkan hubungan korelasi antara jarak/letak sumber pencemar dengan kadar E.Coli sangat lemah (nilai korelasi pearsonnya sangat kecil $(0,013)$. Uji korelasi untuk variabel independen kedua menunjukkan bahwa kondisi fisik (SGL) tidak mempunyai pengaruh yang signifikan terhadap kadar Coliform ( $p$ value 0,558 ). Sedangkan untuk kadar E.Coli menunjukkan adanya keterkaitan antara konstruksi (SGL) dengan kadar E.Coli, walaupun hubungan ini sangat lemah karena $p$ value nya 0,067 . Variabel independen yang ketiga menjelaskan perilaku masyarakat sangat berpengaruh terhadap kadar Coliform dalam air (SGL) yang ditunjukkan oleh ( $p$ value) sebesar $0.001(<0,05)$. Kata Kunci : Pencemaran air tanah, kandungan bakteriologis, coliform, e.coli, Pidie Jaya
\end{abstract}

\section{Pendahuluan}

Air merupakan salah satu kebutuhan pokok manusia karena dalam menjalankan fungsi kehidupan sehari-hari manusia sangat tergantung pada air. Sekitar tiga per empat bagian dari tubuh kita terdiri dari air dan tidak seorang pun dapat bertahan hidup lebih dari 4-5 hari tanpa minum air. Selain itu, air juga dipergunakan untuk memasak, mencuci, mandi, dan keperluan sehari-hari lainnya (Chandra, 2007). Untuk memenuhi semua kebutuhan tersebut manusia paling banyak menggunakan air bersih yang bersumber dari air tanah (sumur gali). 


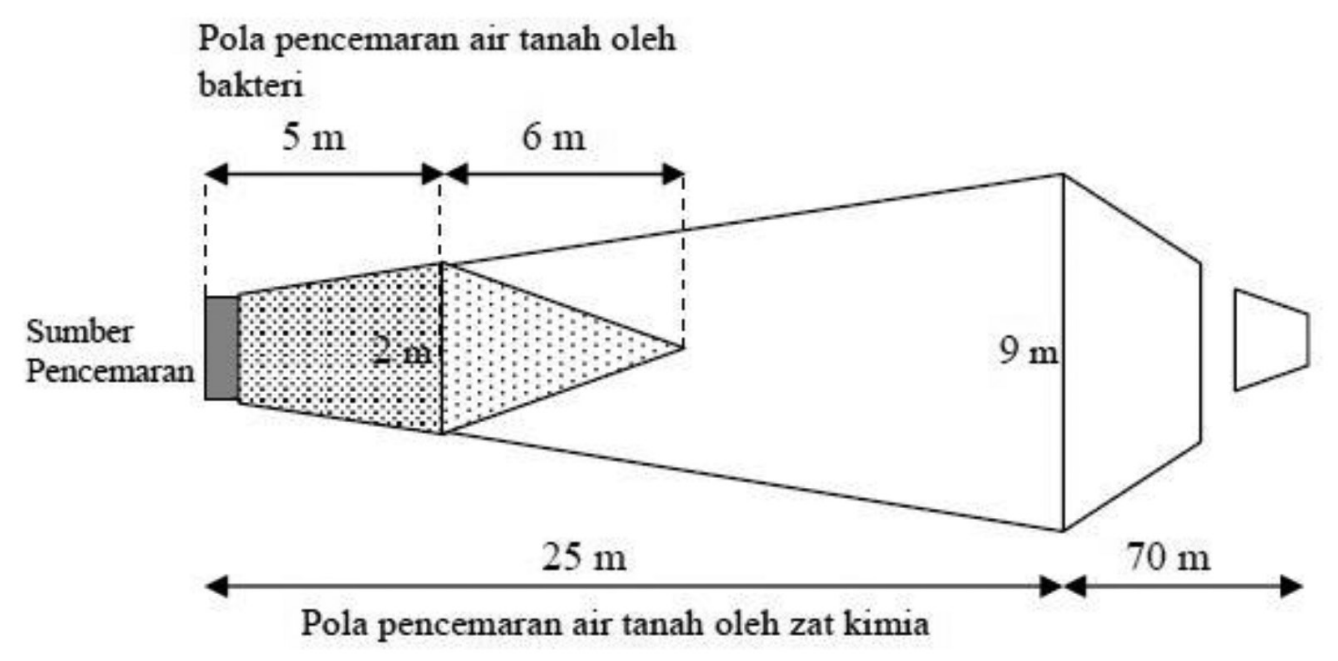

Gambar 1. Pola Penyebaran mikroorganisme dan bahan kimia dalam pencemaran terhadap air tanah di sekitarnya Sumber : Kusnoputranto., H, 1985.

Berdasarkan Peraturan Menteri Kesehatan RI No. 736/MENKES/PER/VI/2010 tentang tata laksana pengawasan air minum, air minum adalah air yang melalui proses pengolahan yang syarat kesehatan atau tanpa proses pengolahan dan dapat langsung diminum, dan air bersih yang digunakan untuk kebutuhan rumah tangga harus memenuhi syaratsyarat tertentu baik secara fisik, biologi, maupun kimia. Pada kenyataannya air tanah yang tersedia untuk dipergunakan tidak selalu memenuhi standar kesehatan. Terlebih lagi bagi masyarakat yang menggunakan air yang berasal dari sumur. Jika air tersebut berasal dari sumur yang letaknya dekat dengan sumber limbah, maka air tersebut akan lebih mudah terkontaminasi oleh cemaran atau polutan. Sumber pencemaran terdiri dari polutan alami (mineral dan mikroorganisme) serta polutan buatan. Polutan buatan dapat berupa residu (sisa) bahan kimia yang dibuat oleh manusia, sedangkan polutan buatan dapat berasal dari limbah rumah tangga, industri maupun pertanian.

Zat-zat pencemar, terutama yang dapat menghasilkan bakteri pathogen sangat berbahaya karena dapat menyebabkan munculnya berbagai jenis penyakit. Kandungan bakteri dalam air sebenarnya tidak berbahaya jika tidak melampaui batas ambang. Masalah pencemaran air tanah secara bakteriologis akan muncul ketika jumlah bakteri yang terkandung dalam sumber air bersih melebihi batas aman. Banyak faktor yang memungkinkan meningkatnya kandungan bakteri pathogen dalam air tanah seperti jarak sumber pencemar yang terlalu dekat dengan sumber air tanah dalam hal ini sumur gali (SGL), kondisi fisik dan kontruksi sumur gali yang tidak memenuhi syarat, dan perilaku masyarakat.

Masyarakat pedesaan merupakan kelompok masyarakat yang paling banyak menggunakan air sumur sebagai sumber air bersih bagi kebutuhan rumah tangga. Seperti halnya masyarakat Dusun Keude Lueng Putu yang tinggal di sekitar pasar tradisional, yang mana pemukiman dan aktifitas domestik nya sangat padat, memiliki kemungkinan yang besar untuk mengalami masalah pencemaran air tanah. Jumlah keseluruhan penduduk Dusun Keude Lueng Putu adalah 759 jiwa yang terbagi kedalam 135 KK (Data dari Puskesmas Kecamatan Bandar baru, 201). Berdasarkan data dari puskemas Bandar Baru, dalam dua tahun terakhir jumlah pasien penderita diare melonjak drastis yaitu mencapai 108 jiwa/tahun.

Tabel 1. Distribusi jarak sumber pencemar ke SGL

\begin{tabular}{lccccc}
\hline \multicolumn{1}{c}{ Jenis Sumber Pencemar } & $\begin{array}{c}\text { Jumlah } \\
\text { SGL }\end{array}$ & $\begin{array}{c}\text { Memenuhi } \\
\text { Syarat }\end{array}$ & $\begin{array}{c}\text { Frekuensi } \\
\text { Tidak } \\
\text { Syarat }\end{array}$ & $\begin{array}{c}\text { Tidak } \\
\text { Memenuhi } \\
\text { Syarat (\%) }\end{array}$ \\
\hline $\begin{array}{l}\text { Jamban/tangki septik } \\
\text { Tempat pembuangan } \\
\text { organik }\end{array}$ & sampah & 12 & 3 & 9 & 75 \\
\hline
\end{tabular}

Sumber: Dusun Keude Lueng Putu (2013) 
Tabel 2. Distribusi kondisi fisik dan konstruksi SGL

\begin{tabular}{ccc}
\hline $\begin{array}{c}\text { Klasifikasi Kondisi Fisik dan } \\
\text { Konstruksi SGL }\end{array}$ & Jumlah SGL & $\%$ \\
\hline Buruk & 5 & 41,67 \\
Baik & 7 & 58,33 \\
\hline Total & 12 & 100 \\
\hline
\end{tabular}

Sumber: Dusun Keude Lueng Putu (2013)

Kasus tersebut sudah tergolong sebagai kasus luar biasa (KLB).

Permasalahan utama dalam penelitian ini adalah tingkat pencemaran air tanah di Dusun Keude Lueng Putu yang dititik beratkan pada kadar kandungan Total Koliform. Yang kemudian data tentang kualitas air sumur gali secara biologis akan menegaskan ada tidaknya kontribusi air sumur gali yang tercemar terhadap melonjaknya angka penderita diare di Dusun Keude Lueng Putu.

Fokus penelitian adalah hanya pada tingkat pencemaran air sumur gali yang digunakan oleh masyarakat Dusun Keude Lueng Putu, dan limbah domestik yang dimaksud adalah limbah yang berasal dari WC/tangki septik dan sumber limbah organik. Kemudian jarak aman yang diamati hanya jarak dari tangki septik dan sumber limbah organik ke sumur. Aspek pencemaran air yang diteliti adalah hanya pencemaran secara biologis yaitu menentukan apakah kadar Total Koliform dalam air sumur gali masih berada dalam batas normal atau tidak.

\section{Tinjauan Pustaka}

\subsection{Pencemaran Air}

Pencemaran air adalah masuknya atau dimasukkannya makhluk hidup, zat, energy dan atau komponen lain ke dalam air oleh kegiatan manusia, sehingga kualitas air turun sampai ke tingkat tertentu yang menyebabkan air tidak dapat berfungsi sesuai dengan peruntukannya. Sumber pencemar yang paling umum berasal dari limbah industri, pertanian dan permukiman.

Ketika sumber-sumber air tersebut tercemar maka berbagai kegiatan manusia yang membutuhkan air seperti untuk irigasi pertanian, bahan baku air minum, sebagai saluran pembuangan air hujan dan air limbah, bahkan sebenarnya berpotensi sebagai objek wisata akan terganggu. Dari sekian banyak sumber air yang ada, air tanah merupakan sumber air yang sangat perlu untuk dijaga kualitasnya, karena kebanyakan masyarakat menggunakan air tanah yang berasal dari sumur gali atau sumur bor untuk kebutuhan seharihari seperti, untuk air minum, mengolah makanan, dan lain sebagainya (Priangga, 2013).

\subsection{Air Tanah}

Air tanah merupakan air yang tersimpan atau terperangkap di dalam ruang pori atau lapisan batuan yang mengalami penambahan secara terus menerus oleh alam seperti hujan dan salju, dan kemudian air tersebut bergerak menuju sistem air tanah, dan kemudian kembali lagi ke aliran permukaan, danau, atau lautan (Fabrizi, 2012). Kondisi suatu lapisan tanah membuat suatu pembagian zona air tanah menjadi dua zona besar. (1) Zona air berudara (zone of aeration) adalah suatu lapisan tanah yang mengandung air yang masih dapat kontak dengan udara. Pada zona ini terdapat tiga lapisan tanah, yaitu lapisan air tanah permukaan, lapisan intermediate yang berisi air gravitasi dan lapisan kapiler yang berisi air kapiler. (2) Zona air jenuh (zone of saturation) adalah suatu lapisan tanah yang mengandung air tanah yang relatif tak terhubung dengan udara luar dan lapisan tanahnya atau aquifer bebas (Effendi, 2003).

Air tanah secara umum mempunyai sifat-sifat yang menguntungkan, khususnya dari segi bakteriologis, namun dari segi kimiawi air tanah mempunyai beberapa karakteristik tertentu tergantung pada lapisan kesadahan, kalsium, magnesium, sodium, bikarbonat, $\mathrm{pH}$, dan lain-lainnya. Dengan demikian pemanfaatan air tanah memiliki beberapa keuntungan dan kerugian. Dari segi keuntungan, air tanah pada umumnya bebas

Tabel 3. Distribusi perilaku pengguna air SGL

\begin{tabular}{|c|c|c|}
\hline $\begin{array}{c}\text { Klasifikasi Perilaku Pengguna } \\
\text { SGL }\end{array}$ & Frekuensi & $\%$ \\
\hline Buruk & 5 & 41,67 \\
\hline Baik & 7 & 58,33 \\
\hline Total & 12 & 100 \\
\hline
\end{tabular}

Sumber: Dusun Keude Lueng Putu (2013) 
Tabel 4. Distribusi kualitas bakteriologis air SGL berdasarkan jumlah coliform

\begin{tabular}{lcc}
\hline $\begin{array}{c}\text { Kategori Kualitas Bakteriologis } \\
\text { Air Berdasarkan Jumlah Coliform }\end{array}$ & $\begin{array}{c}\text { Jumlah } \\
\text { SGL }\end{array}$ & \% \\
\hline Tidak Memenuhi Syarat Kesehatan & 6 & 50 \\
Memenuhi Syarat Kesehatan & 6 & 50 \\
\hline Total & 12 & 100 \\
\hline
\end{tabular}

Sumber: Dusun Keude Lueng Putu (2013)

Tabel 5. Distribusi kualitas bakteriologis air SGL berdasarkan jumlah E. Coli

\begin{tabular}{|c|c|c|}
\hline $\begin{array}{l}\text { Kategori Kualitas Bakteriologis } \\
\text { Air Berdasarkan Jumlah E. Coli }\end{array}$ & $\begin{array}{l}\text { Jumlah } \\
\text { SGL }\end{array}$ & $\%$ \\
\hline Tidak Memenuhi Syarat Kesehatan & 2 & 20 \\
\hline Memenuhi Syarat & 8 & 80 \\
\hline Total & 10 & 100 \\
\hline
\end{tabular}

Sumber: Dusun Keude Lueng Putu (2013)

dari bakteri patogen, dapat dipakai tanpa pengolahan lebih lanjut, paling praktis dan ekonomis untuk mendapatkan dan membagikannya, dan lapisan tanah yang menampung air biasanya merupakan tempat pengumpulan air alami. Disamping keuntungan, air tanah juga memiliki beberapa kerugian, antara lain air tanah sering kali mengandung banyak mineralmineral seperti Fe, Mn, Ca dan sebagainya dan biasanya membutuhkan pemompaan (Effendi, 2003).

Banyak faktor yang dapat mempengaruhi kualitas air tanah. Menurut rangkuman yang dibuat oleh Effendi (2003), kualitas air dapat dipengaruhi oleh faktor fisika, kimia dan biologi. Syarat fisika air bersih yaitu air tidak berwarna, tidak berasa, dan tidak berbau. Syarat kimia air bersih yaitu air tidak mengandung zat-zat kimia yang membahayakan kesehatan manusia. Syarat biologi yaitu air tidak mengandung mikroorganisme atau kuman-kuman penyakit. Sedangkan syarat radioaktif yaitu air tidak mengandung unsur-unsur radioaktif yang dapat membahayakan kesehatan.

Pencemaran air tanah adalah suatu keadaan dimana air tanah tersebut telah mengalami penyimpangan dari keadaan normalnya. Keadaan normal air masih tergantung pada faktor penentu, yaitu kegunaan air itu sendiri dan asal sumber air (Wardhana, 1995). Ketika limbah cair dibuang ke tanah, partikel tanah berfungsi sebagai filter, mencegah kandungan limbah yang berukuran besar dan meloloskan cairan untuk meresap ke dalam tanah. Zat berbahaya yang terlarut dalam air ikut meresap ke dalam tanah mencemari air tanah yang ada.

Beberapa sumber pencemaran air tanah adalah seperti limbah yang berasal dari kegiatan-kegiatan industri baik yang bersifat padat atau pun cair, karena limbah yang dihasilkan dari kegiatan industri ini jika tidak ditangani dengan tepat akan sangat berbahaya bagi lingkungan, terutama kualitas air tanah (Ginting, 2007), limbah yang berasal dari kegiatan perikanan dan pertanian juga berpotensi untuk mencemari air tanah, dan yang paling sering terjadi di daerah pemukiman penduduk adalah pembuangan limbah domestik yang tidak sesuai dengan aturan sanitasi yang benar.

Kegiatan-kegiatan yang menghasilkan limbah dan menjadi penyebab pencemaran air dapat berupa limbah industri, pertambangan, pertanian, rumah tangga, dan sebagainya (Djajadiningrat dan Amir, 1993). Sebagian besar air tanah belum tercemar dan aman untuk digunakan, namun apabila sampai tercemar, maka pembersihan dan pemurnian akan sangat sukar. Ditambah lagi pemurnian secara alami berjalan dengan sangat lambat. Untuk itu tindakan yang patut adalah menjaga dengan ketat agar air tanah tidak terkontaminasi (Effendi, 2003). Tindakan preventif dapat dimulai dengan memahami benar apa saja zat yang berpotensi sebagai pencemar air. Pencemar air dapat menentukan indikator yang terjadi pada air lingkungan. Pencemar air dikelompokkan ke dalam tiga kategori; bahan buangan organik, bahan buangan anorganik, dan bahan buangan zat kimia. Bahan buangan organik pada umumnya berupa limbah yang dapat membusuk atau terdegradasi oleh mikroorganisme, sehingga hal ini dapat mengakibatkan semakin berkembangnya mikroorganisme, dan mikroba patogen pun ikut juga berkembangbiak yang mana hal ini dapat mengakibatkan munculnya 
Tabel 6. Hubungan antara jarak sumber pencemar dan kadar coliform dalam air SGL

\begin{tabular}{lcc}
\hline $\begin{array}{l}\text { Hubungan Antara Jarak Sumber } \\
\text { Pencemar Dan Kadar Coliform }\end{array}$ & $\begin{array}{c}\text { Person } \\
\text { Corelation }\end{array}$ & Sig. (2-tailed)/P value \\
\hline Jarak sumber pencemar & 1 & - \\
Kadar Coliform dalam air $S G L$ & -359 & .252 \\
N & 12 & 12 \\
\hline
\end{tabular}

Tabel 7. Hubungan antara jarak sumber pencemar dan kadar E. Coli dalam air SGL

\begin{tabular}{lcc}
\hline $\begin{array}{l}\text { Hubungan Antara Jarak Sumber } \\
\text { Pencemar Dan Kadar Coliform }\end{array}$ & $\begin{array}{c}\text { Person } \\
\text { Corelation }\end{array}$ & Sig. (2-tailed)/P value \\
\hline Jarak Sumber Pencemar & 1 & - \\
Kadar E. Coli Dalam Air SGL & .013 & .968 \\
$\mathrm{~N}$ & 12 & 12 \\
\hline
\end{tabular}

berbagai macam penyakit.

Pencemar yang terakhir adalah bahan buangan zat kimia. Bahan buangan zat kimia banyak ragamnya seperti bahan pencemar air yang berupa sabun dan deterjen, pestisida, zat warna kimia, larutan pembersih kulit dan zat radioaktif. Zat kimia ini di lingkungan air merupakan racun yang mengganggu dan dapat mematikan hewan air, tanaman air dan mungkin juga manusia.

Pola pencemaran bakteri dan kimia terhadap air dan tanah dengan jarak yang ditempuh tergantung beberapa faktor, faktor yang terpenting adalah porositas tanah. Pola pencemaran oleh bakteri dapat digambarkan seperti Gambar 1.

\subsection{Indikator Kualitas Air Secara Bakteriologis}

Pengukuran kualitas air bersih secara bakteriologis dilakukan dengan melihat keberadaan organisme golongan coli (koliform) sebagai indikator. Koliform total telah lama diakui sebagai indikator bakteriologi yang cocok berkenaan dengan kualitas air karena bakteri ini mudah dideteksi dalam air dan mudah dikualifikasi. Walaupun hasil pemeriksaan bakteri coli tak dapat secara langsung menunjukan adanya bakteri patogen, tetapi dapat memberi kesimpulan bahwa kehadiran bakteri coli dengan jumlah tertentu dalam air dapat digunakan sebagai indikator adanya jasad patogen.

Koliform tinja adalah bakteri Gram negatif tidak membentuk spora, tumbuh pada suasana aerobik atau

Tabel 8. Tabulasi silang hubungan kategori kondisi fisik dan konstruksi SGL dengan kadar Coliform dalam air

\begin{tabular}{|c|c|c|c|c|c|c|}
\hline \multirow{3}{*}{$\begin{array}{c}\text { Kondisi Fisik dan Konstruksi } \\
\text { Sumur Gali }\end{array}$} & \multicolumn{4}{|c|}{$\begin{array}{c}\text { Kadar Coliform Dalam Air } \\
\text { SGL }\end{array}$} & \multirow{3}{*}{ Total } & \multirow{3}{*}{$\begin{array}{c}\mathrm{P} \\
\text { value }\end{array}$} \\
\hline & \multicolumn{2}{|c|}{ MS } & \multicolumn{2}{|c|}{ TMS } & & \\
\hline & $\mathbf{N}$ & $\%$ & $\mathbf{N}$ & $\%$ & & \\
\hline Baik & 4 & 66 & 3 & 50 & 7 & 05 \\
\hline Buruk & 2 & 33 & 3 & 50 & 5 & \\
\hline Kadar Coliform Dalam Air SGL & 6 & $100 \%$ & 6 & $100 \%$ & 12 & \\
\hline
\end{tabular}

Tabel 9. Tabulasi silang hubungan kategori kondisi fisik dan konstruksi SGL dengan kadar E.coli dalam air

\begin{tabular}{|c|c|c|c|c|c|c|}
\hline \multirow{3}{*}{$\begin{array}{c}\text { Kondisi Fisik dan Konstruksi } \\
\text { Sumur Gali }\end{array}$} & \multicolumn{4}{|c|}{$\begin{array}{c}\text { Kadar E.Coli Dalam Air } \\
\text { SGL }\end{array}$} & \multirow{3}{*}{ Total } & \multirow{3}{*}{$\begin{array}{c}\mathrm{P} \\
\text { value }\end{array}$} \\
\hline & \multicolumn{2}{|c|}{ MS } & \multicolumn{2}{|c|}{ TMS } & & \\
\hline & $\mathbf{N}$ & $\%$ & $\mathbf{N}$ & $\%$ & & \\
\hline Baik & 7 & 70 & 0 & 0 & 7 & \\
\hline Buruk & 3 & 30 & 2 & 100 & 5 & 0,067 \\
\hline Kadar E. Coli Dalam Air SGL & 6 & $100 \%$ & 2 & $100 \%$ & 12 & \\
\hline
\end{tabular}


Tabel 10. Tabulasi silang hubungan kategori perilaku masyarakat dengan kadar Coliform dalam air

\begin{tabular}{|c|c|c|c|c|c|c|}
\hline \multirow{3}{*}{ Perilaku Masyarakat } & \multicolumn{4}{|c|}{$\begin{array}{c}\text { Kadar Coliform Dalam Air } \\
\text { SGL }\end{array}$} & \multirow{3}{*}{ Total } & \multirow{3}{*}{$\begin{array}{c}\mathrm{P} \\
\text { value }\end{array}$} \\
\hline & \multicolumn{2}{|c|}{ MS } & \multicolumn{2}{|c|}{ TMS } & & \\
\hline & $\mathbf{N}$ & $\%$ & $\mathbf{N}$ & $\%$ & & \\
\hline Baik & 6 & 100 & 0 & 0 & 6 & $0_{1}$ \\
\hline Buruk & 0 & 0 & 6 & 100 & 6 & 0,1 \\
\hline Kadar Coliform Dalam Air SGL & 6 & $100 \%$ & 6 & $100 \%$ & 12 & \\
\hline
\end{tabular}

Tabel 11. Tabulasi silang hubungan kategori perilaku masyarakat dengan kadar E.coli dalam air

\begin{tabular}{|c|c|c|c|c|c|c|}
\hline & & & \multicolumn{2}{|c|}{$\begin{array}{c}\text { Kadar E.Coli Dalam Air } \\
\text { SGL }\end{array}$} & \multirow[b]{2}{*}{ Total } & \multirow[b]{2}{*}{ p value } \\
\hline & & & $\begin{array}{l}\text { Memenuhi } \\
\text { Syarat }\end{array}$ & $\begin{array}{c}\text { Tidak } \\
\text { Memenuhi } \\
\text { Syarat }\end{array}$ & & \\
\hline \multirow{6}{*}{$\begin{array}{l}\text { Kategori } \\
\text { Perilaku } \\
\text { Masyarakat }\end{array}$} & Baik & Count & 6 & 0 & 6 & \multirow{4}{*}{0,121} \\
\hline & \multirow{3}{*}{ Buruk } & $\begin{array}{l}\text { \% within kadar E. Coli dalam air } \\
\text { SGL }\end{array}$ & $60 \%$ & $0 \%$ & $50 \%$ & \\
\hline & & Count & 4 & 2 & 6 & \\
\hline & & $\begin{array}{l}\text { \% within kadar } E \text {. Coli dalam air } \\
\text { SGL }\end{array}$ & $40 \%$ & $100 \%$ & $50 \%$ & \\
\hline & \multirow[t]{2}{*}{ Total } & Count & 10 & 2 & 12 & \\
\hline & & $\begin{array}{l}\text { \% within kadar E. Coli dalam air } \\
\text { SGL }\end{array}$ & $100 \%$ & $100 \%$ & $100 \%$ & \\
\hline
\end{tabular}

fakultatif anaerob. Bakteri tersebut hidup di usus manusia dan hewan berdarah panas, sedangkan di air dapat tahan hidup pada suhu $200 \mathrm{C}$ selama 1 minggu sampai dengan 1 bulan.

Adanya koliform tinja dalam air adalah berasal dari kontaminasi tinja manusia atau binatang. Bakteri koliform tinja umumnya terdapat dalam jumlah besar di usus manusia dan binatang berdarah panas. Pada penyediaan air yang tidak diolah, pencemaran tinja terjadi tergantung dari aliran air permukaan atau adanya penyerapan limbah cair rumah tangga ke dalam lapisan tanah. Pada air yang diolah, kontaminasi dapat terjadi karena disinfeksi yang tidak memadai atau tingginya kekeruhan air baku.

\subsection{Sumur Gali}

Salah satu sumber air bersih yang dimanfaatkan oleh masyarakat adalah sumur gali, merupakan bangunan penyadap air atau pengumpul air tanah dengan cara menggali. Kedalaman sumur bervariasi antara 5m - 20m dari permukaan tanah tergantung pada kedudukan muka air tanah setempat dan juga morfologi daerah. Air tanah dari sumur gali dimanfaatkan untuk keperluan rumah tangga terutama untuk minum, masak, mandi, dan mencuci (Ditjen PPM dan PLP, 1995).

\subsection{Peranan Air terhadap Penularan Penyakit}

Peranan air dalam penularan penyakit adalah disebabkan keadaan air itu sendiri sangat membantu dan sangat baik untuk kehidupan mikrobiologis. Air juga merupakan tempat berkembangbiak mikrobiologi dan juga sebagai tempat tinggal sementara (perantara) sebelum mikrobiologi berpindah ke manusia.

Dalam hal ini ada 4 macam cara di mana penyediaan air dapat mempengaruhi transmisi penyakit dari seseorang ke orang lainnya yaitu dengan cara Water Borne, Water Washed, Water Based, dan Vektor Insekta. Water borne disease adalah penyakit yang ditransmisikan bila organisme penyebab penyakitnya (patogen) yang berada di dalam air terminum oleh orang atau hewan sehingga menimbulkan infeksi. Water borne disease ini dalam kenyataannya dapat disebarkan tidak hanya lewat air, tetapi juga melewati setiap sarana yang memungkinkan bahan tinja untuk memasuki mulut (jalur faecal oral), misalnya lewat makanan yang terkontaminasi. Water borne disease meliputi penyakit-penyakit: tifoid, kholera, disentri dan hepatitis. Melalui cara Water Washed, penularan penyakit ini berkaitan erat dengan air bagi kebersihan umum alat-alat terutama alat-alat dapur dan kebersihan perorangan. Yang selanjutnya 
adalah penularan dengan cara Water Based, cara ini memerlukan penjamu (host) perantara yang hidup di air, misalnya siput air (Ditjen PPM dan PLP, 1995 dan Kusnoputranto, 1997).

\subsection{Perilaku Kesehatan}

Perilaku manusia sebagai reaksi dapat bersifat sederhana maupun bersifat kompleks. Perilaku lewat suatu proses keputusan yang diteliti dan beralasan, dampaknya terbatas pada norma-norma subjektif atau keyakinan mengenai apa yang orang lain inginkan agar diperbaiki. Secara sederhana teori ini mengatakan bahwa seseorang akan melakukan suatu perbuatan apabila ia memandang perbuatan itu positif dan bila ia percaya bahwa orang lain ingin agar ia melakukan yang berhubungan dengan kesehatan (Azwar, 2005).

Perilaku kesehatan pada dasarnya adalah respon seseorang terhadap stimulus yang berkaitan dengan sakit dan penyakit, sistem pelayanan kesehatan, makanan, serta lingkungan. Perilaku terhadap lingkungan kesehatan (environmental health behavior) adalah respon seseorang terhadap lingkungan yang berhubungan dengan air bersih yaitu penggunaan air bersih untuk kesehatan. Perilaku sehat adalah pengetahuan, sikap, dan tindakan proaktif untuk memelihara dan mencegah resiko terjadinya penyakit serta berperan aktif dala gerakan kesehatan masyarakat (Notoatmojo, 2007).

\subsection{Pengendalian Pencemaran Air Tanah}

Problematika pencemaran air tanah memerlukan upaya penanganan yang serius dan menyeluruh karena air tanah merupakan sumber air yang paling bagus untuk dikonsumsi. Meskipun berdasarkan letak sumbernya air tanah tidak mudah tercemar. namun ketika limbah cair tidak dikelola dengan tepat maka limbah tersebut akan dengan mudah diserap oleh tanah dan akhirnya mencapai badan air yang jelas akan mengganggu kualitas air tanah dan menimbulkan berbagai masalah kesehatan (Soeparman dan Suparmin, 2002). Dengan demikian, permasalahan ini membutuhkan tindakan penanggulangan yang tepat. Berdasarkan berbagai sumber literatur, masalah ini dapat ditanggulangi antara lain dengan pengadaan sistem pengelolaan limbah rumah tangga yang benar dan pendekatan edukatif terhadap masyarakat.

\section{Metodelogi Penelitian}

Penelitian ini dilakukan dengan cara pengambilan sampel air sumur, kemudian dilakukan uji laboratorium untuk mengetahui tingkat pencemaran air sumur tersebut secara biologis. Penelitian ini juga dilakukan dengan cara observasi langsung ke lapangan untuk mengukur jarak sumur dari sumber limbah organik. Populasi dalam penelitian ini adalah adalah $10 \%$ dari jumlah populasi yaitu 12 unit sumur gali (SGL).

Teknik sampling yang digunakan untuk penarikan sampel adalah teknik Sampel Acak Sederhana (Simple Random Sampling), karena struktur geografis Dusun Keude Lueng Putu cenderung datar maka setiap unit populasi sumur gali memiliki kesempatan yang sama untuk dijadikan sampel. Menurut Sugiyono (2011), salah satu cara untuk mengambil sampel secara acak sederhana adalah dengan mengambil undian.

Dalam penelitian ini pengambilan undian merupakan cara yang paling praktis karena jumlah sampel hanya 12 . Prosedurnya adalah dengan memberi nomor pada setiap unit populasi dari 1 sampai nomor terakhir yaitu 121. Kemudian mengundinya satu per satu. Pengundian dilakukan sebanyak 12 kali karena itu merupakan jumlah sampel yang diinginkan, dan semua nomor yang terundi dianggap sebagai sampel.

\section{Hasil Dan Pembahasan \\ 4.1. Analisis Univariat}

Analisa univariat dilakukan untuk mengetahui perbedaan proporsi dari tiap-tiap variabel yang diteliti (Marsono, 2009). Variabel-variabel yang dianalisis dalam penelitian ini adalah sebagai berikut.

\section{a. Letak Sumber Pencemar}

Sumber pencemar dalam penelitian ini dititikberatkan pada dua sumber, yaitu jarak jamban/ tangki septik ke sumur gali (SGL) dan jarak tempat pembuangan sampah (TPS) organik ke SGL. Jamban merupakan sumber pencemar utama jika tidak dikelola dengan baik. Kotoran manusia atau fesies sangat berpotensi mencemari SGL jika jarak tangki septik $<11 \mathrm{~m}$, sehingga air dari jamban meresap dan mencemari SGL. Limbah rumah tangga yang tidak dikelola dengan baik sangat berpotensi mencemari SGL. Limbah rumah tangga yang dimaksud dalam penelitian ini adalah TPS organik. Jika jarak TPS organik $<11 \mathrm{~m}$, maka potensi pencemaran SGL akan sangat besar.

Jarak yang aman (memenuhi syarat) dari sumber pencemar ke SGL adalah $>11$ m (Berdasarkan SNI 032916-1992). Dari hasil observasi langsung diperoleh tabel jarak sumber pencemar seperti yang ditunjukkan pada Tabel.1.

Tabel 1 menunjukkan 75\% SGL berjarak kurang dari $11 \mathrm{~m}$ dari tangki septik dan 50\% SGL berjarak kurang dari 11 m dari TPS organik. Dari 12 sumur yang diuji, hanya 3 sumur $(25 \%)$ yang memenuhi syarat jarak yang aman dari sumber pencemar (tangki septik dan TPS organik) seperti yang direkomendasikan 
dalam SNI 03-2916-1992.

\section{b. Kondisi Fisik dan Konstruksi SGL}

Kondisi fisik dan konstruksi SGL diukur melalui checklist. Checklist ini terdiri atas 6 item yang harus diamati. Berdasarkan rentang nilai, klasifikasi variabel ini terbagi atas dua kondisi; buruk (skor 0 3) dan baik (skor $4-6$ ).

Tabel 2 menunjukkan bahwa dari 12 sumur yang diuji, 5 sumur memiliki kondisi fisik dan konstruksi yang buruk $(41,67 \%)$ dan 7 sumur atau 58,33\% berkonstruksi baik.

\section{c. Perilaku Masyarakat}

Perilaku masyarakat diukur dengan berpedoman pada kuesioner. Variabel ini terbagi dua, yaitu penggunaan air SGL dalam masyarakat dan perilaku pengguna air SGL. Berdasarkan hasil kuesioner, semua responden $(100 \%)$ menggunakan air SGL untuk keperluan sehari-hari. Hal ini dikarenakan ketiadaan air PDAM pada dusun yang di teliti, sehingga masyarakat menggunakan air SGL untuk mandi, mencuci dan sebagai sumber air minum.

Perilaku masyarakat dalam menggunakan air SGL diukur dengan kuesioner dengan rentang nilai perilaku adalah $0-8$ yang terbagi dalam 2 klasifikasi, yaitu 'buruk' dengan rentang nilai $0-4$ dan 'baik' yang memiliki rentang nilai $5-8$. Hasil yang diperoleh dapat dilihat pada Tabel 3.

Tabel 3 menunjukkan bahwa 58,33\% masyarakat memiliki perilaku penggunaan air SGL yang baik. Semua masyarakat (100\%) memasak air SGL yang dipergunakan untuk minum. Setengah dari jumlah responden menggunakan kaporit/tawas untuk membersihkan air sumur, serta hanya sepertiga dari total responden yang memiliki pompa air. Lebih dari setengah responden, atau $58,33 \%$, yang meletakkan kerikil/pecahan bata/pecahan marmer pada dasar sumur dan $100 \%$ responden tidak membersihkan saluran pembuangan air limbah (SPAL) dengan teratur. Sebanyak $75 \%$ responden tidak mempertimbangkan jarak SGL dengan sumber pencemar dan $41.67 \%$ tidak mempertimbangkan konstruksi SGL yang baik.

\section{d. Kualitas Bakteriologis Air SGL}

Dari 12 sumur yang diuji pada UPTD Laboratorium Kesehatan Banda Aceh, 50\% memiliki jumlah Coliform diatas ambang batas yang direkomendasikan (memenuhi syarat kesehatan), yaitu $50 / 100 \mathrm{~mL}$. Walaupun demikian, hanya 2 sumur yang diuji (20\%) memiliki jumlah bakteri $E$. Coli yang tidak memenuhi syarat kesehatan $(50 / 100 \mathrm{~mL})$. Distribusi kualitas bakteriologis air SGL ini dapat dilihat pada Tabel 4 dan 5 .

\subsection{Analisis Bivariat}

Penelitian ini memiliki tiga variabel independen dan satu variabel dependen, maka akan diperoleh tiga variasi hubungan.

\section{a. Lokasi Pencemar Terhadap Kualitas Bakteriologis Air}

Data jarak dan kualitas bakteriologis diperoleh melalui pengukuran dan uji laboratorium, maka data ini dapat diklasifikasikan sebagai data rasio. Menurut Suharto, alat analisis (uji hipotesis asosiatif) statistik parametrik yang lazim digunakan untuk data rasio salah satunya adalah Pearson Correlation Product Moment atau Pearson's r. Tabel 6. dan 7. menunjukkan korelasi antara jarak sumber pencemar (tangki septik dan TPS organik) dan kualitas bakteriologis air SGL (Coliform dan E. Coli).

Dari Tabel 6. dan 7, nilai korelasi Pearson antara jarak sumber pencemar dan kadar Coliform dalam air SGL adalah -0,359 dan antara Jarak Sumber Pencemar dan Kadar E.Coli adalah 0,013. Sedangkan $p$ value untuk masing-masing hubungan adalah 0,252 dan 0,968 .

\section{b. Kondisi Fisik dan Konstruksi SGL Terhadap Kualitas Bakteriologis Air}

Kondisi fisik dan konstruksi SGL terbagi atas dua kategori, buruk (rentang nilai $0-3$ ) dan baik (rentang nilai 4-6). Alat analisis statistik non-parametrik yang umum digunakan untuk data nominal ataupun ordinal adalah chi-square. Hasil tabulasi silang kondisi fisik dan kostruksi SGL terhadap kualitas bakteriologis (Coliform dan E. Coli) yang diperoleh dengan menggunakan SPSS dapat dilihat pada Tabel 8 dan 10 .

Dari uji statistik chi-square untuk hubungan antara kategori kondisi fisik dan konstruksi SGL dengan kadar Coliform diperoleh nilai $\mathrm{p}$ value 0,558 (Tabel 8). Sedangkan untuk hubungan antara kategori kondisi fisik dan konstruksi SGL dengan kadar E. Coli $\mathrm{p}$ value yang diperoleh adalah 0,067 (Tabel 9).

\section{c. Perilaku Masyarakat Terhadap Kualitas Bakteriologis Air SGL}

Variabel perilaku masyarakat dikategorikan dalam 2 jenis, yaitu buruk (rentang nilai $0-4$ ) dan baik (rentang nilai $5-8$ ). Alat analisis statistik non-parametrik yang umum digunakan untuk data nominal ataupun ordinal adalah chi-square. Hasil tabulasi silang perilaku masyarakat terhadap kualitas bakteriologis (Coliform dan E.Coli) yang diperoleh dengan menggunakan SPSS dapat dilihat pada tabel 
10 dan 11.

\section{Kesimpulan Dan Saran}

\subsection{Kesimpulan}

Beberapa hal yang dapat disimpulkan adalah sebagai berikut:

1. Berdasarkan hasil analisa data secara menyeluruh dapat disimpulkan bahwa kualitas bakteriologis air (SGL) dapat dipengaruhi oleh aspek-apek berikut, yaitu letak sumber pencemar, kondisi fisik dan konstruksi SGL, dan perilaku masyarakat dalam menggunakan air SGL. Walaupun untuk beberapa aspek hubungannya lemah dan tidak terlalu signifikan.

2. Jika kadar Coliform dan E.Coli yang mempengaruhi kualitas bakteriologis air SGL meningkat, maka penderita penyakit Diare di daerah Keude Lueng Putu akan meningkat. Untuk menghindari hal ini, masyarakat harus mulai peduli pada letak dan proses pembuatan SGL serta memiliki perilaku yang baik dalam menggunakan air SGL.

\subsection{Saran}

Saran-saran berdasarkan kesimpulan dari hasil penelitian ini adalah sebagai berikut:

1. Untuk mengurangi resiko pencemaran air tanah (SGL) di Desa Keude Lueng Putu, bagi petugas Dinas kesehatan kabupaten dan puskesmas harus melakukan upaya penyuluhan tentang bagaimana cara mengelola dan mengolah air sumur (SGL) sehingga kualitas air sumur (SGL) memenuhi syarat kesehatan berdasarkan peraturan menteri kesehatan RI No. 416/MEKES/PER/ IX/1990, persyaratan kualitas air bersih.

2. Pengontrolan kualitas SGL dengan melakukan uji laboratorium secara berkala juga sangat membantu masyarakat dalam menjaga kualitas air SGL.

3. Masyarakat diharapkan untuk lebih aktif dalam menjaga kualitas air tanah (SGL) dengan memperhatikan perilakunya sebagai pengguna (SGL). Di antara hal-hal yang dapat dilakukan adalah dengan merujuk ke aturan-aturan yang telah direkomendasikan oleh pemerintah ketika membangun sumur dan memeliharanya. Masyarakat harus mempertimbangkan letak/ jarak (SGL) dari sumber pencemar serta banggunan untuk sebuah sumur yang akan di bangun, dan juga membersihkan saluran pembuangan air limbah secara berkala.

\section{Daftar Pustaka}

Anonim, (2003). Instalasi Pengolahan Air, Jakarta: Departemen Kesehatan RI.

Direktorat Jenderal Pemberantasan Penyakit Menular dan Penyehatan Lingkungan Permukiman, (1993). Juklak/Juknis Pengawasan Kualitas Air Aspek Mikrobiologis dan Biologi Air Minum dan Air Bersih, Jakarta:.

Direktorat Jenderal Pemberantasan Penyakit Menular dan Penyehatan Lingkungan Permukiman, (1995). Manual Teknis Upaya Penyehatan Air, Jakarta

Azwar, S, (2005). Sikap Manusia, Teori dan Pengukurannya, Yogyakarta: Pustaka Pelajar Offset.

Chandra, Budiman. (2007) Pengantar Kesehatan Lingkungan, Jakarta: Penerbit Buku Kedokteran, Hal. 124, dan 144-147.

Djajadiningrat, Surna T dan Harry Harsono Amir, (1993). Penilaian Secara Cepat SumberSumber Pencemaran Air, Tanah, dan Udara, Yogyakarta: Gadjah Mada University Press.

Effendi, Hefni, (2003). Telaah Kualitas Air (Bagi Pengelolaan Sumber Daya dan Lingkungan Perairan), Yogyakarta: KANISIUS.

Fabrizi, Lara, Groundwater, http://www.lenntech. com/groundwater/definitions .htm, diakses pada 20 Desember 2012.

Ginting, Perdana, (2003). Sistem Pengelolaan Lingkungan dan Limbah Industri, Bandung: Yrama Widya

Kantor Kecamatan Bandar Baru, (2013). Data Penduduk Bandar Baru Tahun 2013, Lueng Putu.

Notoatmodjo, S. (2007). Promosi Kesehatan dan Ilmu Perilaku. Jakarta : Rineka Cipta.

Peraturan Menteri Kesehatan RI No. 736/MENKES/ PER/VI/2010, (2010). Tata Laksana Pengawasan Kualitas Air Minum, Jakarta.

Permenkes RI No. 416/MENKES/PER/IX/1990, (1990). Persyaratan Kualitas Air Bersih. Jakarta

Menteri Kesehatan RI No. 492, (2010). Persyaratan Kualitas Air Minum. Jakarta

Priangga,R. A, Pencemaran Pada Air, http:// blog2.tp.ac.id/priangga ramadhana abdillah/2013/01/02/pencemaran-air/, diakses pada 15 Februari 2013.

SNI 03-291-1992, Spesifikasi Sumur Gali untuk Sumber Air Bersih, Jakarta,

Soeparman dan Suparmin, (2002). Pembuangan Tinja 
dan Limbah Cair: Suatu Pengantar, Jakarta: EGC

Sugiyono. (2011). Metode Penelitian Kuantitatif, Kualitatif, dan R\&D. Bandung: AFABETA

Suharto, (2003). Pengertian dan Jenis Data Nominal, Ordinal, Interval dan Data Rasio. http://suhartoumm.blogspot.com/2008/12/ transformasi-variabel-ordinal.html, diakses pada 14 September 2013.

Wardhana, W.A, (1995). Dampak Pencemaran Lingkungan, Jakarta: Andi Offset Yogyakarta. 